\title{
KASTURI TOBACCO LEAF FLAVONOIDS AS BIOACTIVE COMPOUNDS IN PERIODONTAL ANTIBACTERIAL MUCOADHESIVE GEL
}

\author{
QONITA NAFILAH FEBI ${ }^{1}$, MALIHATUL ROSIDAH ${ }^{1}$, DERI ABDUL AZIS ${ }^{1}$, ENDAH PUSPITASARI ${ }^{2}$, \\ ARI SATIA NUGRAHA ${ }^{3}$, BANUN KUSUMAWARDANI ${ }^{*}$
}

\begin{abstract}
${ }^{1}$ Department of Biomedical Sciences, Faculty of Dentistry, University of Jember, Jawa Timur 68121, Indonesia. ${ }^{2}$ Department of Pharmaceutical Biology, Faculty of Pharmacy, University of Jember, Jawa Timur 68121, Indonesia. ${ }^{3}$ Drug Utilisation and Discovery Research Group, Faculty of Pharmacy, University of Jember, Jawa Timur 68121, Indonesia. Email: banun_k.fkg@unej.ac.id
\end{abstract}

Received: 17 July 2019, Revised and Accepted: 21 September 2019

\section{ABSTRACT}

Objective: The tobacco leaves are a rich source of many biologically active substances. Flavonoids are one of the bioactive substances contained in tobacco leaves with a wide range of pharmacological properties. This study has been aimed to formulate the antibacterial periodontal gel containing the flavonoids fraction of Kasturi tobacco (Nicotiana tabacum) leaves.

Methods: Fraction flavonoids obtained from methanolic extracts of tobacco leaves, which have been purified from nicotine. Different concentrations of flavonoids fraction $(0,25,0,5,1,2$, and $4 \mathrm{mg} / \mathrm{ml})$ were prepared with Carbopol-974P. The strength of flavonoid gel adhesion in ex vivo mucosa was tested by the falling liquid film method. Evaluation of in vitro antibacterial agent was followed by the disk diffusion method.

Results: The flavonoid gels have better adhesion parameters (time, strength, and distance) than gel bases. The antimicrobial by the zone of inhibition studies proved that flavonoids periodontal gels with concentrations of $4 \mathrm{mg} / \mathrm{ml}$ are highly active against Porphyromonas gingivalis with the zone of inhibition $>10 \mathrm{~mm}$ which was higher than quercetin gel formulations (control groups).

Conclusion: Gel formulation containing the flavonoids fraction of Kasturi tobacco ( $N$. tabacum) leaves could be a good candidate for periodontal gel with good mucoadhesive gel and antibacterial agent.

Keywords: Antibacterial periodontal gel, Flavonoid, Periodontitis, Tobacco leaves.

(C) 2019 The Authors. Published by Innovare Academic Sciences Pvt Ltd. This is an open access article under the CC BY license (http://creativecommons. org/licenses/by/4. 0/) DOI: http://dx.doi.org/10.22159/ajpcr.2019.v12i11.34967

\section{INTRODUCTION}

Gingivitis and periodontitis are the most common oral diseases which it initial stage is characterized by inflammation of the gingival tissue called gingivitis [1], further periodontitis is characterized by inflammation of the supporting tissues of the teeth, progressive damage to the periodontal ligament, and alveolar bone together with the formation of periodontal pockets and gingival recession. The immune response to the interaction of microorganisms and inflammatory cells in the tissues around the teeth contributes to the development of this disease. The enzymes and toxins released by periodontal pathogenic bacteria exaggerate the destruction of the periodontium [2]. Anaerobic Gram-negative bacteria involved in the development of periodontal disease are Porphyromonas gingivalis, Bacteroides forsythus, and Actinobacillus actinomycetemcomitans [3]. The bacteria colonization in the periodontal pocket constructs a firmly attached biofilm on the teeth and gingiva surface which the film helps bacteria fight antibiotics. Bacteria can be interconnected in biofilms, and this action helps gene transmission that results in resistance to antibiotics and the growth of resistant microorganism species [4].

In most cases, the important treatment modality is by controlling inflammation through dental plaque and calculus removal to reduce pathogenic microorganisms [5], but this procedure is not able to inhibit bacterial growth by systemic antibiotic therapy. As the etiologies of periodontal disease correlate to various types of bacterial infection, there is no ideal and effective antibiotic for all pathogens, and the improper different antibiotics uses can lead to medical side effects [6]. The shortterm efficacy and inconsistency of antiseptic mouthwash and also the side effects of systemic antibiotics encourage the use of a therapeutic system locally. The use of minocycline gel and metronidazole gel in the subgingival area is the development of drug delivery systems [7]. This system has several advantages including reducing prescription drugs, increasing drug concentration in the target tissue, reducing drug side effects, and lowering the dosage frequency [8]. Natural products such as flavonoids are capable to prevent the development of infections. Flavonoids are safe and cost-effective with neglectable side effects. Local drug delivery of natural products to the periodontal pocket is an additional therapy other than dental root planing and scaling for the treatment of periodontal disease [9].

With the increasing prevalence of antibiotic-resistant bacterial infections, the use of natural ingredients, such as flavonoids, is increasingly attracting potential utility as antibiotic replacement therapy or adjuvant therapy. Flavonoids have been known to possess antibacterial potency against various pathogenic microorganisms [10]. Therefore, the development of flavonoids as herbal mucoadhesive active compounds is very necessary and important to improve the success of periodontal disease treatment. The bioactive fraction used in this development of mucoadhesive gel is flavonoids from Kasturi tobacco leaf wastes in which our preliminary research on the crude extract showed antimicrobial activity. Nicotine constituent removal was the most important part in producing a satisfactory antimicrobial assay [11]. The preliminary research data encourage us to further carry out extraction and fractionation of nicotine-free flavonoids from the waste of Kasturi tobacco leaves.

Kasturi tobacco leaf waste is a tobacco leaf located in the lower stem, brownish-yellow in color, damaged or perforated leaf shape, and has a low selling value; hence, it is often discarded and destroyed by burning. Disposal of this waste will cause serious problems because 
tobacco leaf waste contains highly toxic nicotine. Thus, efforts need to be made to use controlled tobacco leaf waste to avoid harmful effects on the environment and make Kasturi tobacco leaf waste as a source of flavonoids that can be used as a basis for biopharmaceutical development to treat periodontal disease.

\section{METHODS}

Fractionation of flavonoids from the waste of Kasturi tobacco leaf Kasturi tobacco leaf waste was collected from tobacco plantations in Pakusari, Jember, Indonesia. Tobacco leaves are dried at room temperature for 2 days before further drying in an oven for $24 \mathrm{~h}$ at $40^{\circ} \mathrm{C}$. To dried tobacco leaf powder (50 g), methanol $(400 \mathrm{~mL})$ was added and the mixture was then stirred with an orbital shaker at $150 \mathrm{rpm}$ for $24 \mathrm{~h}$. The solution was obtained through filtration which the supernatant was volume reduced $(200 \mathrm{~mL})$ through vacuum evaporation. To the methanol extract $(200 \mathrm{~mL})$, hexane $(20 \mathrm{~mL})$ was added before stirring with a magnetic stir for 10 min to form two layers. The top layer was removed, while the bottom layer is washed again with hexane $(20 \mathrm{~mL})$. This process is repeated 15 times. All the upper layers were evaporated with a rotary evaporator until a thick extract $(20 \mathrm{~mL})$. A portion of the thick extract $(10 \mathrm{~mL})$, hydrogen chloride $(10 \%, 20 \mathrm{~mL})$, distilled water $(10 \mathrm{~mL})$, and ethyl acetate $(20 \mathrm{~mL})$ was added and the mixture was stirred under a magnetic stir for $10 \mathrm{~min}$ to form two layers. The top ethyl acetate layer was separated and collected. This fractionation process was repeated 3 times. The top layer is a solution rich in flavonoids, while the lower layer is a solution rich in nicotine. The top layer that is rich in flavonoids is taken and tested for the nicotine content with the Dragendorff test to make sure there are no nicotine traces in the layer. The result of fractionation of flavonoids (the top layer formed) is taken and evaporated. The alkaloid removal followed a standard procedure by Docheva et al. with a modification $[12,13]$.

\section{Flavonoid mucoadhesive gel formulation}

Flavonoids with a series concentrations of $0.25,0.5,1,2$, and $4 \mathrm{mg} / \mathrm{mL}$ were dispersed in dimethyl sulfoxide $1 \%$ along with a gel base consisting of Carbopol-974P, triethanolamine, and aquades (2:5:100). This mixture is slowly stirred to homogenize and forms a thick gel mass. The gel is poured into a petri dish and left overnight for stabilization. Metronidazole $(2 \%)$ and quercetin $(50 \mu \mathrm{M})$ gels were used as the control.

\section{Ex vivo flavonoid gel adhesion}

The strength of the flavonoid gel adhesion was performed through the falling liquid film method. In this study, the rat gastric mucous layer was used as a model to determine the strength of gel adhesion. The gastric mucosa of rats was cleaned with $0.9 \%$ sodium chloride and was cut $(1.5 \mathrm{~cm} \times 3 \mathrm{~cm})$. The rat's gastric mucosa is placed between two glass plates and the top of which was a hole with a $2 \mathrm{~cm}$ diameter. Flavonoid gel (200 mg) was attached to the steel plate as a buffer. The steel plate was then attached to the texture analyzer tool pipe. The texture analyzer was managed using a computer with stable microsystem activation. The steel plate will slowly drop into the glass

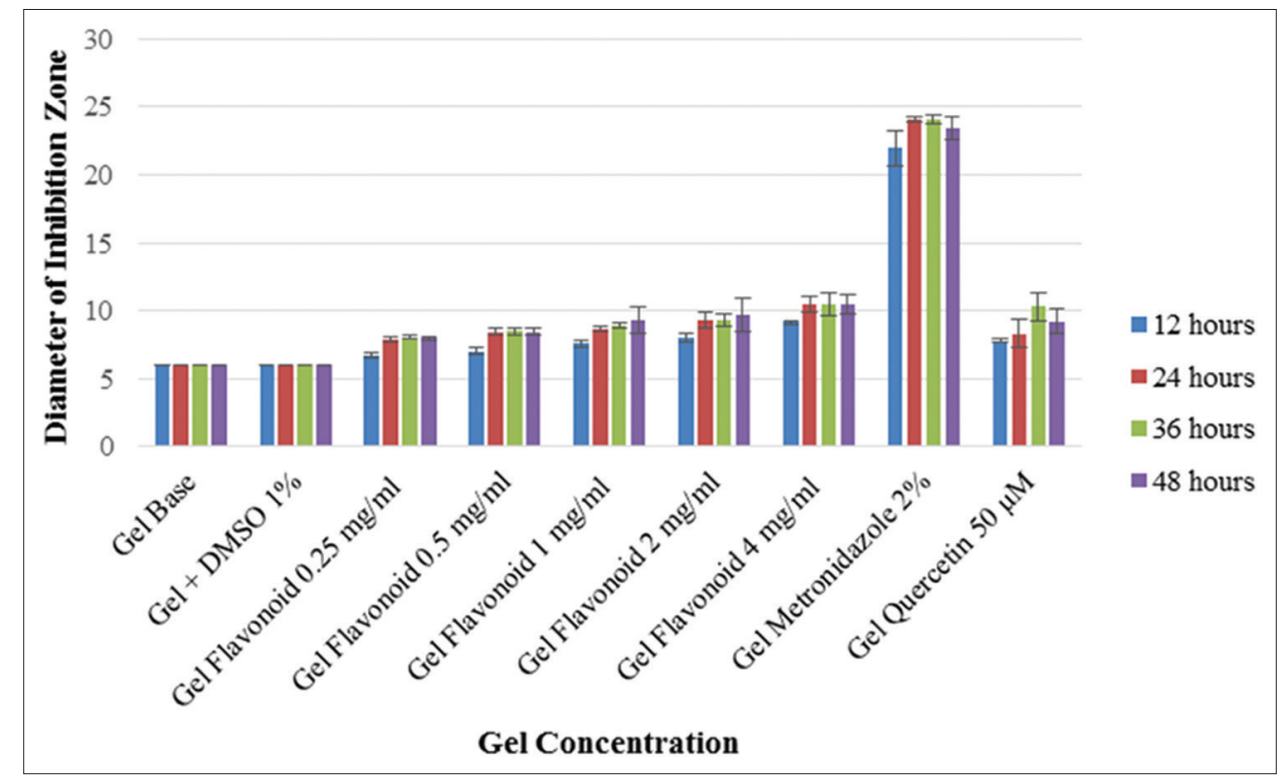

Fig. 1: Porphyromonas gingivalis inhibition zone in incubation 12, 24, 36, and $48 \mathrm{~h}$ in all control and treatment groups. Significance values in all groups at each time of exposure showed a value of $p<0.05$

Table 1: Diameter of Porphyromonas gingivalis growth inhibition zone

\begin{tabular}{|c|c|c|c|c|c|}
\hline \multirow[t]{2}{*}{ Groups } & \multicolumn{4}{|c|}{ Diameter of inhibition zone (mm) } & \multirow[t]{2}{*}{$P$} \\
\hline & $12 \mathrm{~h}$ & $24 \mathrm{~h}$ & $36 \mathrm{~h}$ & $48 \mathrm{~h}$ & \\
\hline Gel base & $6 \pm 0.00$ & $6 \pm 0.00$ & $6 \pm 0.00$ & $6 \pm 0.00$ & - \\
\hline Gel+DMSO 1\% & $6 \pm 0.00$ & $6 \pm 0.00$ & $6 \pm 0.00$ & $6 \pm 0.00$ & - \\
\hline Gel flavonoid $0.25 \mathrm{mg} / \mathrm{ml}$ & $6.71 \pm 0.17$ & $7.87 \pm 0.16$ & $8.07 \pm 0.09$ & $7.98 \pm 0.15$ & 0.000 \\
\hline Gel flavonoid 0.5 mg/ml & $7.05 \pm 0.32$ & $8.44 \pm 0.266$ & $8.50 \pm 0.29$ & $8.47 \pm 0.24$ & 0.000 \\
\hline Gel flavonoid $1 \mathrm{mg} / \mathrm{ml}$ & $7.58 \pm 0.29$ & $8.70 \pm 0.20$ & $8.93 \pm 0.15$ & $9.30 \pm 0.98$ & 0.009 \\
\hline Gel flavonoid $2 \mathrm{mg} / \mathrm{ml}$ & $8.05 \pm 0.33$ & $9.35 \pm 0.61$ & $9.33 \pm 0.49$ & $9.75 \pm 1.24$ & 0.078 \\
\hline Gel flavonoid $4 \mathrm{mg} / \mathrm{ml}$ & $9.13 \pm 0.16$ & $10.46 \pm 0.55$ & $10.51 \pm 0.84$ & $10.49 \pm 0.71$ & 0.045 \\
\hline Gel metronidazole $2 \%$ & $21.96 \pm 1.31$ & $24.12 \pm 0.17$ & $24.04 \pm 0.33$ & $23.47 \pm 0.85$ & 0.022 \\
\hline Gel quercetin $50 \mu \mathrm{M}$ & $7.79 \pm 0.14$ & $8.31 \pm 1.03$ & $10.29 \pm 1.03$ & $9.24 \pm 0.90$ & 0.019 \\
\hline
\end{tabular}

DMSO: Dimethyl sulfoxide 
Table 2: The flavonoid gels mucoadhesion parameters

\begin{tabular}{llll}
\hline Groups & Time $(\mathbf{s})$ & Force $\mathbf{( g )}$ & Distance $(\mathbf{m m})$ \\
\hline Gel quercetin $50 \mu \mathrm{M}$ & 17.290 & 3.15 & 2.993 \\
Gel flavonoid $4 \mathrm{mg} / \mathrm{ml}$ & 17.135 & 2.78 & 3.146 \\
Gel flavonoid $2 \mathrm{mg} / \mathrm{ml}$ & 17.415 & 3.13 & 2.525 \\
Gel flavonoid $1 \mathrm{mg} / \mathrm{ml}$ & 17.500 & 4.75 & 3.233 \\
Gel flavonoid $0.5 \mathrm{mg} / \mathrm{ml}$ & 18.255 & 5.24 & 4.090 \\
Gel flavonoid $0.25 \mathrm{mg} / \mathrm{ml}$ & 16.970 & 3.53 & 2.830 \\
Gel+DMSO $1 \%$ & 19.545 & 5.03 & 4.233 \\
Gel base & 16.505 & 1.34 & 2.641 \\
\hline
\end{tabular}

DMSO: Dimethyl sulfoxide

plate hole and touch the rat's gastric mucosa, then after a few seconds, the steel plate will rise quickly.

\section{In vitro antibacterial activity of flavonoid gel against $P$. gingivalis}

The antibacterial effect of gel formulations on $P$. gingivalis was evaluated using the disk diffusion method. P. gingivalis ATTC 33277 was cultured in medium blood agar by adding Vitamin $\mathrm{K}$ and kanamycin. Culture media were incubated for $72 \mathrm{~h}$ under anaerobic conditions at $37^{\circ} \mathrm{C} \pm 2^{\circ} \mathrm{C}$. After bacterial growth, the bacterial suspension was prepared in $0.9 \%$ saline and the turbidity was adjusted to a standard of $0.5 \mathrm{McF}$ arland (equivalent to $10^{6} \mathrm{CFU} / \mathrm{ml}$ ) and was then aseptically transferred to the culture medium. Sterile paper discs with a diameter of $5 \mathrm{~mm}$ were then smeared with flavonoid gel concentrations of $0.25,0.5,1,2$, and $4 \mathrm{mg} / \mathrm{ml}$ and were placed on the surface of the plates containing the culture medium within the same distance. The plates were then incubated at $37^{\circ} \mathrm{C} \pm 2^{\circ} \mathrm{C}$ for $48 \mathrm{~h}$ under anaerobic conditions. After this period, the diameter of the resistance zone around the disc was measured in millimeters and the average diameter was recorded. The test is performed as triplicates. Sterile paper discs with base gel were used as negative controls, while metronidazole gel concentrations of $2 \%$ and quercetin gel $50 \mu \mathrm{M}$ were used as positive controls.

\section{Data analysis}

Quantitative data are presented in mean $\pm S D$, compared with ANOVA and followed by post hoc test. Significance values were determined as $\mathrm{p}<0.05$. Data were analyzed by SPSS software.

\section{RESULTS}

Antibacterial test of tobacco leaf flavonoid Kasturi gel on $P$. gingivalis bacteria showed its ability to inhibit bacterial growth in a dosage-dependent manner. The average diameter of the inhibition zone is shown in Table 1 and Fig. 1

The average diameter of the highest inhibition zone of the experiment groups (Table 1 and Fig. 1 ) is indicated by the flavonoid gel $4 \mathrm{mg} / \mathrm{ml}$ at all exposure times and the lowest inhibition zone indicated by the flavonoid gel $0.25 \mathrm{mg} / \mathrm{ml}$ at all times of exposure. However, the average diameter of the flavonoid gel inhibition zone was $4 \mathrm{mg} / \mathrm{ml}$ lower than the $2 \%$ metronidazole gel. Statistical analysis showed that exposure time significantly affected the diameter of the inhibitory zone in the treatment group $(\mathrm{p}<0.05)$.

The mucoadhesive test was carried out to determine the strength of the flavonoid gel of Kasturi tobacco leaf that can attach to mucous tissue in which the experiment indicated the flavonoid gels to have a better adhesion parameters (time, strength, and distance) than the gel base (Table 2).

\section{DISCUSSION}

Exploration of natural materials with biological activity has been part of development of a non-surgical chemotherapeutic treatment strategy in periodontal disease management such as the use of therapeutic agents of flavonoid on local delivery vehicles. The efficacy of antimicrobial agents applied locally in the treatment of periodontitis depends on adequate subgingival delivery of the agent, achieving sufficient contact time between the antimicrobial agent and target microorganisms, and achieving an effective concentration of antimicrobial agents. The local delivery devices provide a potential in therapy improvement where conventional treatment cannot be applied [14].

Flavonoids have been known as a source for antibacterial agents against various pathogenic microorganisms [10]. This study indicated that tobacco leaf flavonoids gel tends to work well as an antibacterial against $P$. gingivalis at 24-h incubation. The antibacterial mechanism of flavonoids is related to inhibition of nucleic acid synthesis, cytoplasmic membrane function, and energy metabolism [15].

Mucoadhesion is the main property for the treatment of periodontal disease. Mucoadhesive drug delivery systems have been introduced as new dosage forms due to their ability to remain in the mucous membranes and release their drug content slowly. The data of this study indicate that the gels have better adhesion parameters (time, strength, and distance) than gel bases. The potential use of the mucoadhesive system as a drug carrier lies in the extension of residence time at the absorption site, thus allowing intensive contact with the epithelial barrier [16]. Thus, the use of bioadhesive molecules aims to maintain preparations at worksites and direct drugs to specific locations or tissues [17]. Therefore, bioadhesive systems that control drug release can improve treatment and maintain effective drug concentrations at the worksite [18].

\section{CONCLUSION}

Based on in vitro antibacterial and mucoadhesion studies, the flavonoid gel $4 \mathrm{mg} / \mathrm{ml}$ was selected as the best formulation. Flavonoid gel $4 \mathrm{mg} / \mathrm{ml}$ showed a satisfactory mucoadhesion property and produced significant growth inhibition zone against $P$. gingivalis. The polymer concentration in the gel base can be used as a controlling drug release rate and for increasing adhesive strength, contact time with the mucosa, and residence time in periodontal pockets. Overall, the gel formulation containing the flavonoids fraction of Kasturi tobacco (Nicotiana tabacum) leaves a good candidate for periodontal gel with good mucoadhesive gel and antibacterial agent.

\section{ACKNOWLEDGMENTS}

This work was partly supported by a "Program Kreativitas Mahasiswa" grant (827/SPK/KM.02.01/2019) from the Ministry of Research, Technology and Higher Education of Indonesia.

\section{AUTHORS' CONTRIBUTIONS}

Conceptualization, B.K.; methodology, B.K., E.P., and A.S.N.; investigation, B.K., E.P., Q.N.F., M.R., and D.A.A.; data curation, Q.N.F., M.R., and D.A.A.; resources, B.K., E.P., Q.N.F., M.R., and D.A.A.; formal analysis and data interpretation, B.K. and E.P.; original draft preparation, B.K., E.P., Q.N.F., M.R., and D.A.A.; and review and editing, B.K. and A.S.N.

\section{CONFLICTS OF INTEREST}

The authors declare that there are no conflicts of interest and all authors participated actively in work. All authors read and approved final version of manuscript for publication.

\section{REFERENCES}

1. Chapple IL, Van der Weijden F, Doerfer C, Herrera D, Shapira L, Polak D, et al. Primary prevention of periodontitis: Managing gingivitis. J Clin Periodontol 2015;42 Suppl 16:S71-6.

2. Jain N, Jain GK, Javed S, Iqbal Z, Talegaonkar S, Ahmad FJ, et al. Recent approaches for the treatment of periodontitis. Drug Discov Today 2008;13:932-43

3. Zambon JJ. Periodontal diseases: Microbial factors. Ann Periodontol 1996;1:879-925.

4. Amoian B, Moghadamnia AA, Vadiati B, Mehrani J. Local application of 
antibiotics in periodontal pockets. J Babol Univ Med Sci 2011;13:82-9.

5. Mlachkova AM, Popova CL. Efficiency of nonsurgical periodontal therapy in moderate chronic periodontitis. Folia Med (Plovdiv) 2014;56:109-15.

6. Rams TE, Degener JE, van Winkelhoff AJ. Antibiotic resistance in human chronic periodontitis microbiota. J Periodontol 2014;85:160-9.

7. Zingale J, Harpenau L, Bruce G, Chambers D, Lundergan W. The effectiveness of scaling and root planing with adjunctive time-release minocycline using an open and closed approach for the treatment of periodontitis. Gen Dent 2012;60:300-5.

8. Medlicott NJ, Rathbone MJ, Holborow DW, Tucker IG. Delivery systems for the administration of drugs to the periodontal pocket. Adv Drug Deliv Rev 1994;13:181-203.

9. Bruschi ML, Jones DS, Panzeri H, Gremião MP, de Freitas O, Lara EH. Semisolid systems containing propolis for the treatment of periodontal disease: In vitro release kinetics, syringeability, rheological, textural, and mucoadhesive properties. J Pharm Sci 2007;96:2074-89.

10. Bakht J, Azra, Shafi M. Antimicrobial activity of Nicotiana tabacum using different solvents extracts. Pak J Bot 2012;44:459-63.

11. Putri RH, Barid I, Kusumawardani B. Daya hambat ekstrak daun tembakau terhadap pertumbuhan mikroba rongga mulut. Stomatognatic 2014;11:27-31.

12. Docheva M, Dagnon S, Statkova-Abeghe S. Flavonoid content and radical scavenging potential of extracts prepared from tobacco cultivars and waste. Nat Prod Res 2014;28:1328-34.

13. Nugraha AS, Pratoko DK, Damayanti YD, Lestari ND, Laksono TA, Addy HS, et al. antibacterial and anticancer activities of nine lichens of Indonesian Java Island. J Biol Act Prod Nat 2019;9:39-46.

14. Larsen T. In vitro release of doxycycline from bioabsorbable materials and acrylic strips. J Periodontol 1990;61:30-4.

15. Petti S, Scully C. Polyphenols, oral health and disease: A review. J Dent 2009;37:413-23.

16. Hägerström H, Edsman K, Strømme M. Low-frequency dielectric spectroscopy as a tool for studying the compatibility between pharmaceutical gels and mucous tissue. J Pharm Sci 2003;92:1869-81.

17. Woodley J. Bioadhesion: New possibilities for drug administration? Clin Pharmacokinet 2001;40:77-84.

18. Huang Y, Leobandung W, Foss A, Peppas NA. Molecular aspects of muco-and bioadhesion: Tethered structures and site-specific surfaces. J Control Release 2000;65:63-71 